\title{
Variation in the natural termite resistance of teak (Tectona grandis Linn. fil.) wood as a function of tree age
}

\author{
Ganis LUKMANDARU ${ }^{1,2 *}$, Koetsu TAKAHASHI ${ }^{3}$ \\ ${ }^{1}$ Department of Forest Product Technology, Faculty of Forestry, Gadjah Mada University, Jogja 55281, Indonesia \\ ${ }^{2}$ United Graduate School of Agricultural Science Iwate University, Morioka 020-8550, Japan \\ ${ }^{3}$ Department of Bioenvironment, Faculty of Agriculture, Yamagata University, Tsuruoka 997-8555, Japan
}

(Received 12 February 2008; accepted 6 June 2008)

Keywords:

Tectona grandis /

tree age /

termite resistance /

color extractive content /

\begin{abstract}
- Tree age is one of the most important factors to affect the natural durability of wood.

- The purpose of this study was to determine the natural termite resistance of heartwood and sapwood of teak (Tectona grandis Linn. fil.) for trees aged 8, 30 and 51 years. Reticulitermes speratus Kolbe was employed as a test termite using a no-choice feeding method.

- The heartwood and sapwood of all of the trees tested exhibited antitermitic activity. Based on the mean mass loss due to termite activity, the sapwood and heartwood regions of 8-year-old trees are the most susceptible to termites while the heartwood regions of the 30-year-old trees showed termite resistance similar to the termite resistance of 51-year-old trees.

- The mass loss is moderately correlated with $n$-hexane extractive content, total extractive content, brightness and redness of the wood.
\end{abstract}

Mots-clés :

Tectona grandis /

âge de l'arbre /

résistance aux termites /

contenu de l'extrait /

couleur

Résumé - Effet de l’âge de l'arbre sur la résistance naturelle du bois de teck (Tectona grandis Linn. fil.) aux termites.

- L'âge de l'arbre est un des facteurs les plus importants de la durabilité du bois.

- Le propos de cette étude était de déterminer la résistance naturelle du bois de cœur et de l'aubier de teck (Tectona grandis Linn. fil.) aux termites, pour des arbres âgés de 8, 30 et 51 ans. Reticulitermes speratus Kolbe a été utilisé comme termite test dans un essai d'alimentation sans choix.

- Le bois de cœur et l'aubier de tous les arbres ont été testés pour leur activité anti-termite. En se basant sur la perte moyenne de masse de bois résultant des activités des termites, l'aubier et le bois de cœur des arbres de 8 ans se sont révélés les plus sensibles, alors que le bois de cœur des arbres de 30 ans a montré une résistance aux termites semblable à celle des arbres de 51 ans.

- La perte de masse était modérément corrélée au contenu de l'extrait n-hexane, à celui de l'extrait total, ainsi qu'à la brillance et à la rougeur du bois.

\section{INTRODUCTION}

Teak (Tectona grandis L. fil.) is the principal commercial timber in Indonesia, particularly on the island of Java. Despite the existence of teak plantations managed by the state-owned company Perum Perhutani which covers $1.210^{6}$ ha in Java, high demand from the wood industries has created a shortage in the supply of raw material. In order to meet this demand, an increase in the quantity of teak produced in 'hutan rakyat' $($ hutan $=$ forest, rakyat $=$ community) or farmland has occurred. According to the Ministry of Forestry of Indonesia, 'hutan rakyat' is defined as "forest grown on land with ownership or other rights" (Departemen Kehutanan, 1995).

\footnotetext{
*Corresponding author: ganisarema@lycos.com
}

Contrary to the practice adopted by Perhutani which employs a felling cycle of 60 years or more, most the farmland stands are focused on obtaining short- to medium-term return on their efforts by harvesting younger trees. The owners commonly cut their trees when they reach an age of 20 to 30 years. Concerns have been raised over the quality of the wood obtained from such younger trees. Logs from these plantations will have a large proportion of sapwood and immature wood, whose properties may differ from those of older trees. With teak, the major concerns are with regard to durability and color.

In terms of durability, teak is valued for its natural termite resistance properties. Ngee et al. (2004) reported teak as a less preferred species against native pest Coptotermes, 
Table I. Description of the sampling and sites.

\begin{tabular}{llll}
\hline Factor & 8 year-old & 30 year-old & 51 year- old \\
\hline Origin & farmland stands & farmland stands & Perhutani plantation \\
Site location (province) & Gunungkidul (Jogja) & Kulonprogo (Jogja) & Randublatung (Central Java) \\
Number of samples & 5 (tree no 1 to 5) & 4 (tree no 6 to 9) & 5 (tree no 10 to 14) \\
Altitude (m) & 450 & 120 & 140 \\
East longitude & $110^{\circ} 30^{\prime}$ & $110^{\circ} 8^{\prime}$ & $111^{\circ} 30^{\prime}$ \\
South latitude & $7^{\circ} 60^{\prime}$ & $7^{\circ} 44^{\prime}$ & $7^{\circ} 05^{\prime}$ \\
Soil type & black calcareous, loam & alluvial, loamy sand & humous margalitic, loamy sand \\
Annual rainfall-range $(\mathrm{mm})$ & $1400-1800$ & $1700-2500$ & $1300-2000$ \\
Temperature range ${ }^{\circ} \mathrm{C}$ & $22-36$ & $18-32$ & $20-34$ \\
Relative humidity & 70 & 76 & 72 \\
Mean diameter $(\mathrm{cm})$ & 10.2 & 27.1 & 36.5 \\
Mean heartwood proportion $(\%)$ & 19.5 & 60.3 & 78.7 \\
Mean sapwood thickness $(\mathrm{cm})$ & 3.1 & 3.3 & 2.1 \\
\hline
\end{tabular}

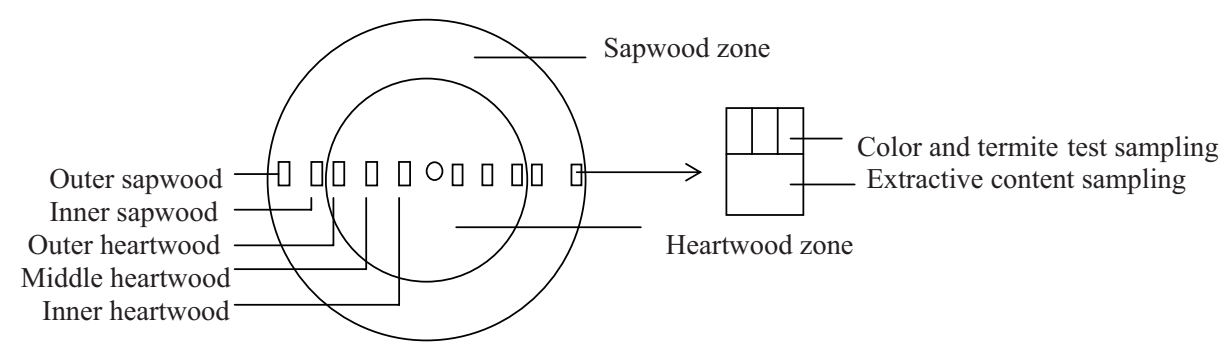

(1)

Figure 1. Sampling position on a cross-section of teak trunk.

Microceratotermes, Globitermes, Macrotermes termites in a preference test. It has problems, however, such as its sapwood with reference to the dry wood termite 'inger-inger' (Neotermes tectonae Damm.) (Subiyanto, 1995). Teak wood was also proved to be naturally resistant against non-native termites (Becker, 1961). There is no doubt that this advantage can be attributed to extractives. Tree age, extractive content and radial position have been reported as affecting the natural termite resistances (Da Costa et al., 1958; 1961; Rudman et al., 1967). The object of this study is to determine the natural termite resistance of heartwood and sapwood of plantation grown teak. Samples have been examined for 8, 30 and 51 years old. A factorial design was used to investigate the effects and interaction of tree age and radial position on termite resistance properties. Analysis of the content of the extractives and the color of the wood were included in the study because these factors are likely to have an effect of the durability of the wood.

\section{MATERIALS AND METHOD}

\subsection{Tree sampling}

Wood samples from sound 8 and 30-year-old trees were obtained randomly from the farmland stands and samples from the 51 year-old trees were obtained from the Perhutani plantation. The condition of the sites and tree characteristics are described in Table I. Discs $5 \mathrm{~cm}$ in thickness from the felled trees were cut at diameter breast height. The test specimens were taken successively from sapwood to heartwood, and divided into five sections diametrically (Fig. 1):
OS: outer sapwood (ca. $0.5 \mathrm{~cm}$ from the bark),

IS: inner sapwood (ca. $0.5 \mathrm{~cm}$ from the heartwood-sapwood boundary),

$\mathrm{OH}$ : outer heartwood (ca. $0.5 \mathrm{~cm}$ from the heartwood-sapwood boundary),

MH: middle heartwood,

IH: inner heartwood (ca. $2 \mathrm{~cm}$ from the pith).

With the limited amount of suitable material available, the $\mathrm{MH}$ and IH zones in the 8-year-old discs and the IS zone in the 51-yearold discs were excluded. Each part from two opposing radii was converted into wood meal by drilling. It was then combined to form a single sample in order to minimize variations between radii. The meal samples were then ground to a size of 40-60 mesh for determination of extractive content. For the termite resistance test and color properties, blocks ca. $5.0(\mathrm{~L}) \times 0.8(\mathrm{~T}) \times 0.8(\mathrm{R}) \mathrm{cm}$ matching samples for extractive content determination (Fig. 1), were stripped from each part and radius. The blocks were then dried at $100{ }^{\circ} \mathrm{C}$ for $3 \mathrm{~h}$, after which they were cooled and weighed.

\subsection{Termite resistance test}

\subsubsection{Termite species}

The subterranean termite Reticulitermes speratus Kolbe, one of the most wood damaging species in Japan, was used in this work. Pine (Pinus densiflora Sieb. et Zucc.) logs containing termites were collected in the mountain area near Tsuruoka, Yamagata and maintained in an environmental chamber at $25{ }^{\circ} \mathrm{C}, 75 \% \mathrm{RH}$ in the laboratory until initiation of the test. Healthy worker termites were taken from these logs and exposed to the wood blocks. 


\subsubsection{No-choice test on wood blocks}

For each test, an air-dried wood block (moisture content 10-12\%) was inserted into a plastic cup $(5.0 \mathrm{~cm} \times 6.0 \mathrm{~cm})$, and placed on $20 \mathrm{~g}$ of sterile sand. The sand was moistened with distilled water regularly to retain a constant relative humidity. Fifty worker termites were added to each cup. Included in the tests for comparative purposes were controls of susceptible pine sapwood blocks and starvation controls containing only sand substrate. Three replicates were measured for each sample, for a total of 171 observations. The cups were placed in the environmental chamber for two weeks. No attempt was made to remove dead termites from the cup during the trial period. To measure the termiticidal activity, surviving termites were counted in first week and at the end of observation. The mass loss was determined to quantify the extent of the termite attack on the wood. A subjective evaluation was performed, whereby all parts tested were classified into the following four classes of resistance according to their mean mass loss values (MML, in $\mathrm{mg}$ ). Classifications were as follows: highly resistant $(0<\mathrm{MML} \leq 5)$, resistant $(5<\mathrm{MML} \leq 10)$, moderately resistant $(10<\mathrm{MML} \leq 15)$, and non resistant $(15<\mathrm{MML})$.

\subsection{Extractive content}

The extractive content was determined for $2 \mathrm{~g}$ (based on oven dry weight) wood meal using a Soxhlet apparatus. Extractions were conducted using a 6-h sequence of $n$-hexane, ethyl acetate (EtOAc) and methanol $(\mathrm{MeOH})$. The solvents were concentrated in a rotary film evaporator, dried, and weighed to determine the $n$-hexane, EtOAc, and $\mathrm{MeOH}$ extractive content based on oven dry wood meal $(\mathrm{m} / \mathrm{m})$. The total extractive content was calculated by determining the sum of all extractive contents.

\subsection{Color measurement}

A portable spectrophotometer NF777 (Nippon Denshoku Ind. Co Ltd.) with a diameter opening of $6.0 \mathrm{~mm}$, illuminant A and tungsten halogen light source was used. Percentage of reflectance data was collected at $20 \mathrm{~nm}$ intervals over the visible spectrum $(400-700 \mathrm{~nm})$. Color measurements were taken for air-dried termite wood block test mentioned above. This was performed before initiation of the antitermite test. The color parameters were measured in the middle of the tangential face (adjacent to meal sample) of each sample. Three measurements were made for each sample and the average values of the measurements were calculated as the different color parameters, designated $\mathrm{L}^{*}, \mathrm{a}^{*}$, and $\mathrm{b}^{*}$. $\mathrm{L}^{*}$ describes brightness (along a brightness axis where $100=$ white or total brightness; and $0=$ black or darkness) of a color. The value $\mathrm{a}^{*}$ describes the redness (along the $\mathrm{X}$ axis red $(+)$ to green $(-)$ ), and the value $b^{*}$ describes the yellowness (along the $\mathrm{Y}$ axis yellow $(+)$ to blue $(-))$.

\subsection{Statistical analysis}

The effects of tree age and radial position on survival rate and mass loss were calculated by analysis of variance (ANOVA) GLM procedures. The effects were taken into account only when significant at the 95\% level using Type III Sums of Squares. The termite survival rates (percentages) were transformed to arc sine for analysis

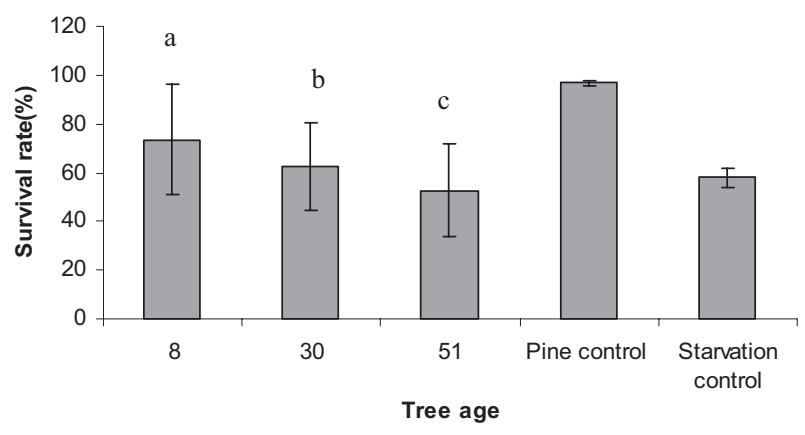

(a)

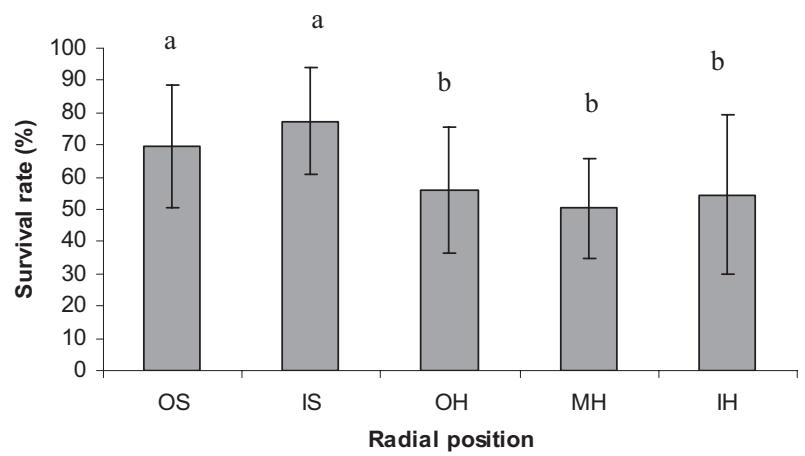

(b)

Figure 2. Survival rate against Reticulitermes speratus on one-week observation of teakwood by tree age and radial position. Mean of 5 trees (8- and 51 year-old) and 4 trees (30-year-old), with the standard deviation error bar. The same letters on the same graphic are not statistically different at $P<0.05$ by Duncan's test. Pine and starvation control are included for the purpose of comparison. OS $=$ Outer sapwood, IS = inner sapwood, $\mathrm{OH}=$ outer heartwood, $\mathrm{MH}=$ middle heartwood, $\mathrm{IH}=$ inner heartwood.

but were presented as untransformed values to facilitate interpretation. Means of extractive content and color measurement were tested by One-way ANOVA. A Duncan test for multiple comparisons was used to show which group means differ. A Pearson correlation analysis was employed for termite resistance parameters, extractive contents and wood color properties. All statistics were performed with SPSS 10.0 software.

\section{RESULTS AND DISCUSSION}

\subsection{Termite resistance}

\subsubsection{Survival rate}

The ANOVA of mean survival rate in the first week indicates that there is no significant tree age and radial position interaction $(p=0.08)$, while the effects of tree age $(p=0.011)$ and radial position $(p=0.002)$ are significant. Comparisons among tree age reveal that the survival rate decreases significantly with tree age (Fig. 2a). Close examination of the mean values within radial position reveals survival rate between the sapwood (69-77\%) and heartwood region (50-56\%) are significantly different (Fig. 2b). The interaction between tree age 


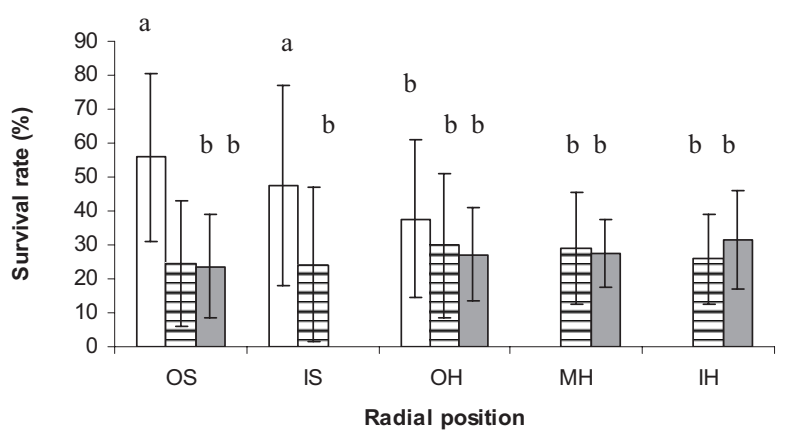

(a)

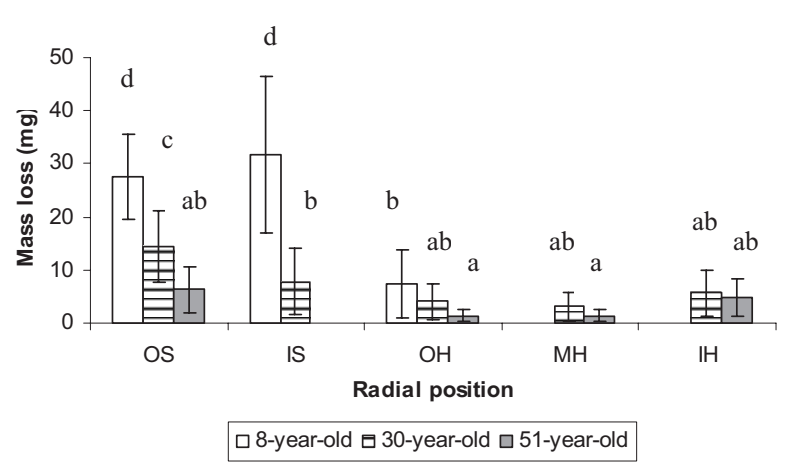

(b)

Figure 3. Survival rate and mass loss against Reticulitermes speratus on 2-week observation of teakwood by tree age and radial position. Mean of 5 trees (8- and 51 year-old) and 4 trees (30-year-old), with the standard deviation error bar. Means survival rate of pine and starvation control were $88.67 \pm 2.30$ and $16.6 \pm 13.30 \%$, respectively. Mean mass loss of pine control was $52.41 \pm 5.69 \mathrm{mg}$. The same letters on the same graphic are not statistically different at $P<0.05$ by Duncan's test. OS = Outer sapwood, IS = inner sapwood, $\mathrm{OH}=$ Outer heartwood, $\mathrm{MH}=$ middle heartwood, $\mathrm{IH}=$ inner heartwood.

and radial position is highly significant $(p=0.002)$ in regards to the mean of survival in the second week. The survival rate means in the second week are shown in Figure 3a. The highest surviving termite levels are obtained at the OS and IS of 8 -year-old trees (47-55\%). No significant differences could be observed between the three tree age groups in the heartwood.

The mean survival rate value of termites under complete starvation control condition is $16 \%$ after the 2 -week test period. The survival rate value of the pine control is $88 \%$. Based on these results, the natural termiticidal activity of teak wood is not thought to be acute. This confirms earlier reports (Da Costa et al., 1958, Rudman et al., 1967), which demonstrated that teak wood is not toxic but merely deters the subterranean Coptotermes lacteus Frogg. and Nasutitermes exitiosus Hill termites. However, the survival rates measured in this work for the termites exposed to teak samples are lower than in those reports. These differences of survival rates may be due to the use of different termite species in this experiment. In a previous study, Becker (1961) observed that the resistance and susceptibility of the wood species varies with every termite tested.
Ngee et al. (2004) suggested a differential feeding preference among Coptotermes species, as well as towards wood species from different geographical localities. Thus, the use of native pests in a bioassay test, e.g. the most aggressive Coptotermes curvignathus Holmgren termites, would provide more information with regard to the natural resistance of teak.

\subsubsection{Mass loss}

The ANOVA of mass loss shows significant tree age and radial position interaction $(p<0.01)$, indicating that the effect of tree age varied with the radial position. Based on MML data (Fig. 3b), heartwood of all ages falls into resistant and highly resistant classes whereas sapwood falls into classes ranging from resistant to non-resistant. The mass loss in the $\mathrm{OH}$ tends to decrease with tree age, the relative mass loss in the $\mathrm{OH}$ of 51 year-old trees $(1.37 \mathrm{mg}$, highly resistant class) is significantly lower when compared to those of 8 year-old trees ( $7.45 \mathrm{mg}$, resistant class). While the IH region is found to be less resistant than the $\mathrm{OH}$ or $\mathrm{MH}$ region, the ANOVA of mass loss between the radial part in the heartwood of both the 30 and 51-year-old groups does not vary significantly. The mass loss of the OS decreases significantly with tree age. The OS of 8 year-old trees is classified as non-resistant (MML $27.68 \mathrm{mg}$ ) while the OS of 51-year-old is classified as resistant (MML $6.30 \mathrm{mg}$ ). The level of activity of the OS of 51-year-old trees is even comparable to that of the $\mathrm{OH}$ of 8-year-old trees. Compared to the control pine sample (MML $52.41 \mathrm{mg}$ ), however, the OS of 8 year-old trees exhibits a higher antifeedant activity. The mass loss in the IS $(7.84 \mathrm{mg})$ are significantly lower than those in the OS (14.52 mg) of 30-year-old trees, but a similar trend is not observed in the sapwood of the 8-year-old groups.

These results seem to be in agreement with previous studies (Da Costa et al., 1958; 1961; Rudman et al., 1967), in that an increase in natural termite resistance with tree age in the heartwood is evidenced. Similar tendencies have also been noted in studies of the decay resistance of teak (Bhat and Florence, 2003; Da Costa et al., 1958, 1961; Haupt et al., 2003; Rudman et al., 1967). The obtained results show the heartwood of 30year-old trees achieves similar termite resistance level to 51year-old trees. This is an encouraging result considering the recent increase of young trees utilization. On the other hand, the termite susceptibility in the sapwood must be taken into consideration, since the percentage of sapwood is relatively high in trees younger than 51 years.

The standard deviation of the mass loss values is large even in the same group. This indicates that wood samples of the same age group and radial part may belong to different classes of antitermitic resistance. A good example of this is the $\mathrm{OH}$ of 30-year-old tree no 9. This is classified as resistant while the $\mathrm{OH}$ of 30 -year-old tree no 7 is classified as moderately resistant (data not shown). With regard to decay resistance, significant variations among tree samples are also found in 5year-old teak (Bhat and Florence, 2003). Differences in termite survival and mass loss are also found among the control group indicating the possibly that slight differences in test conditions occurred between trials. 


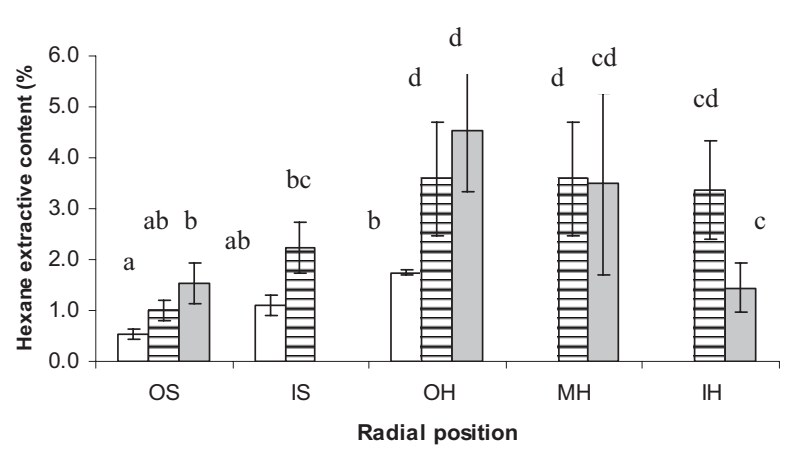

(a)

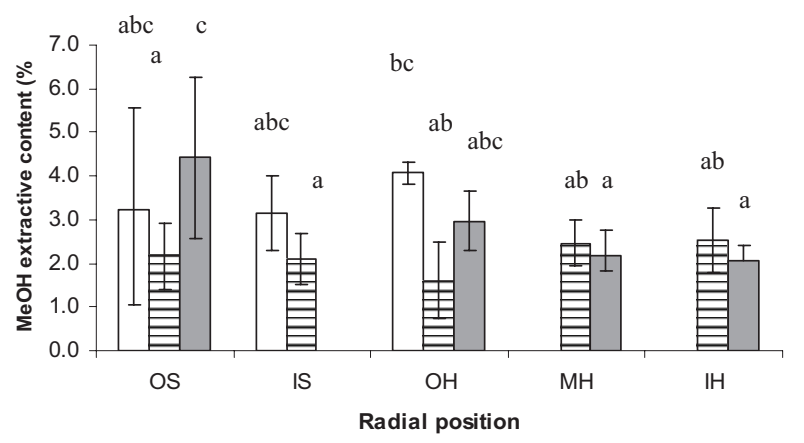

(c)

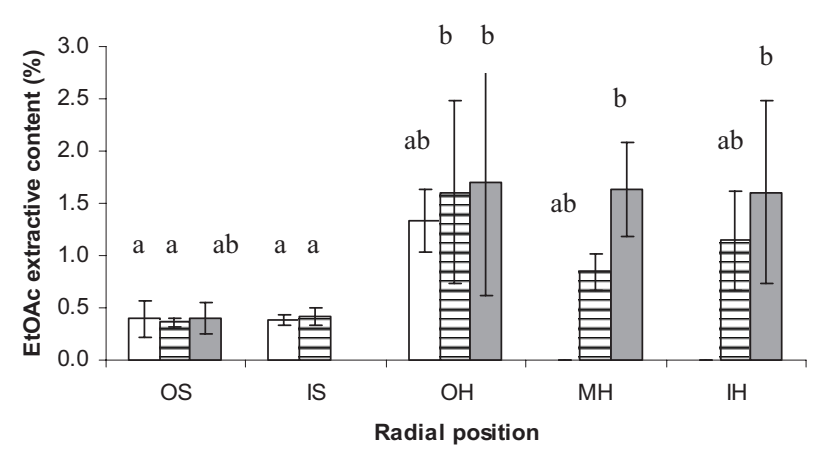

(b)

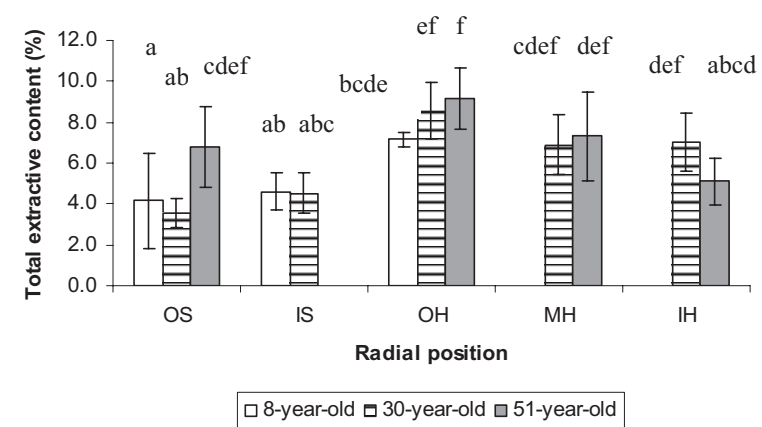

(d)

Figure 4. $n$-hexane, EtOAc, $\mathrm{MeOH}$, and total extractive content (\% oven dried mass $\mathrm{m} / \mathrm{m}$ ) of teakwood by tree age and radial position. Mean of 5 trees (8- and 51 year-old) and 4 trees (30-year-old), with the standard deviation error bar. The same letters on the same graphic are not statistically different at $P<0.05$ by Duncan's test. OS = Outer sapwood, IS = inner sapwood, $\mathrm{OH}=$ Outer heartwood, $\mathrm{MH}=$ middle heartwood, $\mathrm{IH}=$ inner heartwood.

\subsection{Extractive contents}

The $n$-hexane extractive content (NHEC) determinations are shown in Figure 4a. By ANOVA, NHEC levels in the $\mathrm{OH}$ of 30 and 51 year-old trees (4.36 and $4.52 \%$ respectively) are significantly higher compared to those of 8 -year-old trees $(1.74 \%)$. In radial direction, NHEC levels in the IH also differ significantly from those in the $\mathrm{OH}$ and $\mathrm{MH}$ region. The NHEC levels in the OS region tend to increase with tree age. The maximum levels are obtained in the OS of 51-year-old trees $(1.52 \%)$, the difference is significant from the minimum levels in the OS of 8-year-old trees $(0.53 \%)$. The NHEC levels between IS and OS does not differ significantly. The EtOAc extractive content (EEC) determinations are presented in Figure 4b. By ANOVA, the variation among the different tree age in the OS and $\mathrm{OH}$ region is not significant. The ANOVA reveals significant differences are found for radial direction of 30-year-old trees, which the EEC levels in the OS and IS ( 0.36 and $0.41 \%$, respectively) are lower compared to those in the $\mathrm{OH}$ region $(1.69 \%)$. The EEC level variation among the different radial direction in the heartwood is not significant.

The $\mathrm{MeOH}$ extractive content (MEC) determinations are displayed in Figure 4c. In the sapwood, the OS of 51-yearold trees shows the highest MEC level (4.41\%), significantly higher in comparison to the lowest levels in the OS and IS of
30 year-old groups (2.16 and 2.09\%). In the heartwood, even though the maximum MEC levels are obtained in the $\mathrm{OH}$ of 8 year-old trees $(4.07 \%)$, the difference is not statistically significant in comparison to the lower amount in the $\mathrm{OH}$ of 30 and 51-year-old groups (2.59 and $2.96 \%$, respectively). Systematic differences among the different radial direction in the heartwood are not found. The minimum MEC levels in the heartwood are obtained in the $\mathrm{MH}$ and $\mathrm{IH}$ of 51-year-old trees (2.19 and $2.05 \%)$.

Within all age groups, total extractive content (TEC) increases from the pith until the $\mathrm{OH}$ and then decreases towards the OS (Fig. 4d). The radial distribution pattern of the content of the extractives through sapwood and heartwood corresponds to the schemes generally reported by wood chemists. A comparison between the three tree ages indicates an increase of TEC levels in OS and OH. In the sapwood, the maximum TEC levels are obtained in the OS of 51 year-old trees $(6.78 \%)$, which is significantly higher than those of the 8 and 30-yearold groups (4.15 and $3.53 \%$, respectively). TEC levels in the IS are higher than in the OS of 8 and 30-year-old trees, however, an ANOVA shows that this is not statistically significant. The ANOVA also reveals that TEC levels in the $\mathrm{OH}$ of 51 and 30-year-old trees $(9.17$ and $8.53 \%)$ are statistically different from those in the 8-year old trees $(7.15 \%)$. TEC increases significantly from the $\mathrm{IH}$ toward $\mathrm{OH}$ of 51 -year-old trees, but 
without statistical significance in 30-year-old trees. The pattern of TEC with tree age is in agreement with earlier studies by Da Costa et al. (1958) and Narayanamurti et al. (1962). The corresponding values of TEC in this study are slightly higher than those reported by Da Costa et al. (1958), but lower than those reported by Narayanamurti et al. (1962), and Bhat et al. (2005).

EtOAc, a moderately polar solvent, removed the least extractives while $n$-hexane, the least polar solvent or $\mathrm{MeOH}$, the most polar solvent removed the most extractives in a manner depending upon the part of the wood. Sapwood is generally found to contain more methanol extractives in all age groups. This pattern is also observed in the $\mathrm{OH}$ of 8-year-old trees and the IH of 51-year-old trees. This significantly increase of NHEC and TEC levels from IH to $\mathrm{OH}$ of 51-year-old trees, as well as, in the $\mathrm{OH}$ from 8 to 51-year-old groups indicates the increasing content of TEC in the heartwood is mainly attributed to an increase of NHEC level. The tendency of NHEC and MEC in this study is in line with the tendency reported in Narayanamurti et al. (1962), who observed the maximum MEC level is found in the $\mathrm{OH}$ of a 10-year-old tree whilst maximum ether extractive content level is found in the $\mathrm{OH}$ of a 62-year-old teak tree. These gradients have been interpreted to indicate that conversion of polar compounds to less polar compounds increases with time in the heartwood of growing trees. The data suggest that transformation of juvenile wood into more mature wood is characterized by a significant increase in the amount of less polar extractives. By the time a given tree is 30 years old, a relatively large proportion of less polar extractives is obtained in the extractive content of the heartwood region.

\subsection{Color properties}

For sapwood and heartwood region, the brightness index (L*) ranges from 73 to 77 and 54 to 60 , respectively (Fig. 5a). The ANOVA results show that the OS in 51 year-old-trees trees (73.72) give significantly darker color than those in 8 and 30 -year-old trees (76.65 and 76.09 respectively). The brightness level tends to decrease from OS to IS, with statistical significance in 30-year-old trees. The $\mathrm{OH}$ in 8 and 51-year-old trees (54.39 and 53.06, respectively) gives significantly darker color than those in 30 year-old trees (60.57). Systematic differences among the different radial direction in the heartwood are detected in 51-year-old trees, which the brightness index significantly decreases from IH (58.32) to $\mathrm{OH}$ (53.06).

The redness index $\left(\mathrm{a}^{*}\right)$ of the sapwood and heartwood region ranges from 2 to 3 and 4 to 6 , respectively (Fig. 5b). The maximum redness index in the OS (3.94) are measured in 51 year-old trees, the difference is statistically significant in comparison to the lower amount at the OS of 8 and 30-yearold groups (2.97 and 3.50, respectively). The redness index in the $\mathrm{OH}$ fluctuates with tree age; the significant mean maximum redness index is detected in the $\mathrm{OH}$ of 8 -year-old trees (6.66), whereas the minimum index is found in 30-year-old trees (4.69). A radial difference is observed in the heartwood of 51-year-old trees, which redness levels in the $\mathrm{MH}$ and $\mathrm{IH}$

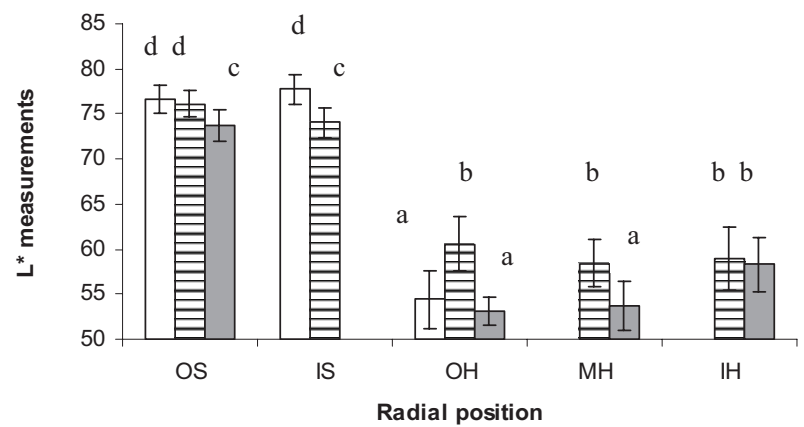

(a)

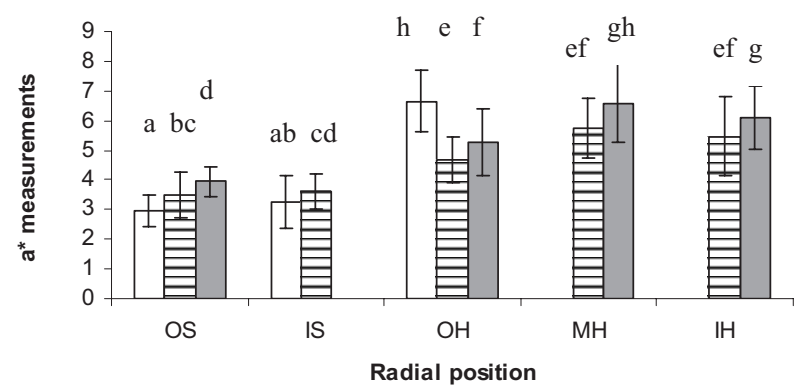

(b)

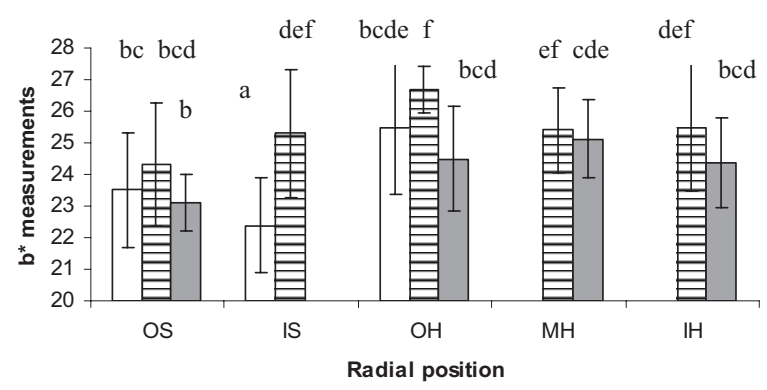

$\square$ 8-year-old $\boxminus 30$-year-old $\square$ 51-year-old

(c)

Figure 5. Color properties in $\mathrm{L}^{*}$ (brightness), $\mathrm{a}^{*}$ (redness) and $\mathrm{b}^{*}$ (yellowness) of teakwood by tree age and radial position. Mean of 5 trees (8- and 51 year-old) and 4 trees (30-year-old), with the standard deviation error bar. The same letters on the same graphic are not statistically different at $P<0.05$ by Duncan's test. OS = outer sapwood, IS = inner sapwood, $\mathrm{OH}=$ Outer heartwood, $\mathrm{MH}=$ middle heartwood, $\mathrm{IH}=$ inner heartwood.

(6.60 and 6.11, respectively) give significantly higher values than those in the $\mathrm{OH}$ region (5.25).

The yellowness index $\left(b^{*}\right)$ of the sapwood and heartwood region ranges approximately from 22 to 25 and 24 to 26, respectively (Fig. 5c). The ANOVA reveals no significant difference in the OS between the groups. The highest yellowness level in the sapwood is detected in the IS of 30-year-old trees (25.31). A significantly higher yellowness index is measured in the $\mathrm{OH}$ of 30 year-old trees (26.67) as compared to the $\mathrm{OH}$ of 8 and 51 year-old trees (25.46 and 24.50, respectively). For both 30 and 51 year-old groups, no significant differences are observed between radial parts in the heartwood. 
Table II. Pearson correlation coefficients $(r)$ for the termite resistance parameters, extractive contents and color properties.

\begin{tabular}{llcc}
\hline Parameters & Survival rate in the first week & Survival rate in the second week & Mass loss \\
\hline$n$-hexane extractive content & $-0.42 * *$ & $-0.34 *$ & $-0.58^{* *}$ \\
EtOAc extractive content & $-0.49 * *$ & $-0.34 *$ & 0.08 \\
MeOH extractive content & 0.11 & $-0.39^{* *}$ & 0.14 \\
Total extractive content & -0.06 & $-0.45^{* *}$ & $-0.51^{* *}$ \\
L* & $0.62 * *$ & $-0.45^{* *}$ & $0.62 * *$ \\
a* & $-0.68 * *$ & -0.08 & $-0.64 * *$ \\
b* & $-0.32 *$ & $-0.31 * *$ \\
\hline
\end{tabular}

** Significant at $1 \%$ level, * significant at $5 \%$ level.

Kokutse et al. (2006) reported the maximum redness value in the heartwood is detected in the $\mathrm{OH}$ area, which differs from the present results, however, the pattern of brightness and yellowness value is in agreement. The corresponding values of brightness and yellowness in the heartwood in this study are slightly higher than previously reported, while the redness values are lower than those of Indian teakwood (Bhat et al., 2005) and Togolese teakwood (Kokutse et al., 2006). The ANOVA reveals that the color index values in the heartwood of 8-yearold trees are almost similar to those of 51-year-old trees. This is an unexpected observation because of the general assumption that the heartwood of younger trees is paler. This position has previously been put forward in a study of oak wood color (Klumpers et al., 1993). The inconsistent results are likely due to variations in silvicultural practice or site condition factors, as suggested by previous reports in teak and other species (Bhat et al., 2005; Nelson et al., 1969; Wilkins and Stamp 1990). The possible effects of those factors are not discussed within the scope of this paper but is worthy of further research.

\subsection{Relationship between termite resistance and extractive contents}

Correlation analysis (Tab. II) confirms moderate negative correlation between the mass loss and NHEC $(r=-0.58)$ as well as between the mass loss and TEC $(r=-0.51)$. This outcome is reasonable since teak extractives are recognized to play a significant role in termite resistance. The variations in mass loss with tree age in the $\mathrm{OS}$ and $\mathrm{OH}$ region are in general accord with the TEC and NHEC distribution trend. Those results confirm that low termite resistance is associated with immature wood. For example, in the 51-year-old group, the trees found to be the most resistant to termites had the highest TEC and NHEC, both in the OS and OH. Da Costa et al. (1958) observed the decrease of mass loss with the increase of TEC level in the $\mathrm{OH}$ region. However, the relationship between mass loss and TEC or NHEC in the radial position of heartwood is not clear in this study. The IH of 51-year-old trees significantly has lower TEC and NHEC than those of the $\mathrm{OH}$, but without statistical significance in the mass loss. This fact may be due to the differences of the toxic component concentrations which are independent to the pattern of extractive content. In studies of the decay resistance of teak, Haupt et al. (2003), Thulasidas and Bhat (2007) suggest that the presence of individual active compounds, even in minor quantities is more significant than the amount of total extractive content.

With regard to chemical consideration, quinones and their derivatives in teak extractives, particularly tectoquinone, have been shown to be toxic to the termites (Rudman and Gay, 1961; Rudman et al., 1958; Sandermann and Simatupang, 1961). This finding supports this papers preliminary study (Lukmandaru and Ogiyama, 2005a; 2005b), which reported that $n$-hexane and less polar fractions of EtOAc soluble extract exhibited antitermitic properties. Furthermore, tectoquinone was identified as being primarily responsible for antitermitic activity. Windeisen et al. (2003) detected tectoquinone and desoxylapachol in petroleum ether soluble extracts. The variations of TEC and NHEC in the same part and group may partly explain the considerable tree-to-tree variation of termite resistance.

Despite the fact that sapwood is known be easily attacked by termites, examination of the termite survival rates and mass loss clearly indicates that teak sapwood exhibits antitermitic activity albeit to a lesser degree than other wood regions. This is more pronounced in the sapwood of 8-year-old trees, which belong to the non-resistant class. This indicates that teak sapwood contains lower levels of compounds that are distasteful, repellent, or toxic to termites. A report by Windeisen et al. (2003) who detected tectoquinone in the sapwood of teak from Panama may support that indication. The high resistance of the sapwood and heartwood in the 51-year-old trees indicates that the aging of toxic constituents is not evident.

\subsection{Relationship between termite resistance and color properties}

The correlation between color and decay resistance in teak heartwood has been investigated. It was found that brightness correlates negatively with mass loss (Kokutse et al., 2006). Bhat et al. (2005) observed a greater content of extractives, more yellow heartwood, and higher decay resistance to brownrot fungi in teak grown at a dry site home garden and plantation than in teak grown in a wet site home garden. In this study, moderate correlations are observed between mass loss with brightness, as well as between mass loss with redness of the wood (Tab. II). Furthermore, correlation analysis also reveals moderate correlation between the survival rate in the first week with brightness or redness. This means the wood 
is more resistant when it is darker and redder. The brightness and redness appear to be related to termite resistance in the sapwood. As expected, the relatively high termite resistance of the IS of 30-year-old trees and OS of 51-year-old trees correspond to darker and redder sapwood. There is no significant difference in brightness and redness among the radial position in the heartwood of 30-year-old trees, which correspond well with no significant differences in mass loss in those regions. However, a similar trend is not observed between the mass loss and color parameters in the $\mathrm{OH}$ regions. Those facts suggest that the relationship between the mass loss and color parameters is complex. As it is known that the color of wood has been related to the quantity and types of wood extractives, this may indicate that the extractives associated with color in the $\mathrm{OH}$ might be independent of those that cause termite resistance. In future studies, investigations of more samples and different termite species will be helpful in determining the relationships between termite resistance and color properties of the wood.

\section{CONCLUSION}

This study demonstrates that immature wood exhibits less natural termite resistance in both the sapwood and heartwood. The survival rate and mass loss level due to termite exposition is dependant on the interaction of tree age and radial position. The survival rate and mass loss levels of sapwood and heartwood of 8-year-old trees are significantly lower than those of 30 and 51-year-old trees. The survival rate and mass loss levels in the heartwood regions of 30 and 51-year-old trees are not statistically different. The survival rate in the first week is moderately correlated to brightness, and redness of the wood. The mass loss is moderately correlated to NHEC, TEC, brightness, and redness of the wood.

Appreciable tree to tree variations are observed in mass loss even in the same stand. It should be mentioned that due to the method of tree sampling, that the in addition to tree age other factors might be involved, including genetic origin, growth condition and silvicultural treatment. The comparison of natural termite resistance parameters should be ideally confirmed with a replication of different tree ages within the same site in order to minimize huge variations and inconsistent results.

Acknowledgements: We express our gratitude to the Ministry of Education, Culture, Sports, Science and Technology, Japan for the financial support of this investigation. Thanks are also directed to Widyanto Nugroho and Tomy Listyanto (Faculty of Forestry, Gadjah Mada University) for their assistance with sample collection. We also thank to Tatsuya Ashitani (Faculty of Agriculture, Yamagata University) and two anonymous reviewers for helpful comments on the manuscript.

\section{REFERENCES}

Becker V.G., 1961. On the examination and estimation of the natural resistance of wood to termites. Holz Roh- Werkst. 19: 278-290.

Bhat K.M. and Florence E.J.M., 2003. Natural decay resistance of juvenile teak wood grown in high input plantations. Holzforschung 57: 453-455.
Bhat K.M., Thulasidas P.K., Florence E.J.M., and Jayaraman K., 2005. Wood durability of home-garden teak against brown-rot and whiterot fungi. Trees 19: 654-660.

Da Costa E.W.B., Rudman P., and Gay F.J., 1958. Investigations on the durability of Tectona grandis, Empire Forestry Review 37: 291-298.

Da Costa E.W.B., Rudman P., and Gay F.J., 1961. Relationship of growth rate and related factors to durability in Tectona grandis. Empire Forestry Review 40: 308-319.

Departemen Kehutanan, 1995. Hutan Rakyat (Community Forest). Biro Hubungan Masyarakat, Departemen Kehutanan, Jakarta.

Haupt M., Leithoff H., Meier D., Puls J., Richter H.G., and Faix O., 2003. Heartwood extractives and natural durability of plantation-grown teakwood (Tectona grandis L.) - a case study. Holz Roh- Werkst. 61: 473-474.

Klumpers J., Janin G., Becker M., and Levy G., 1993. The influences of age, extractive content and soil water on wood color in oak: the possible genetic determination of wood color. Ann. Sci. For. 50: 403409.

Kokutse A.D., Stokes A., Bailleres H., Kokou K., and Baudasse C., 2006. Decay resistance of Togolese teak (Tectona grandis L.) heartwood and relationship with colour. Trees 20: 219-223.

Lukmandaru G. and Ogiyama K., 2005a. Bioactive compounds from ethyl acetate extract of teakwood (Tectona grandis L.f.), Proceedings of the 6th International Wood Science Symposium LIPI-JSPS Core, Bali, Indonesia, August 29-31, 2005, pp. 346-350.

Lukmandaru G. and Ogiyama K., 2005b. Bioactive extract from teakwood (Tectona grandis L.f.), Proceedings of International Symposium on Wood Science and Technology, Volume II: poster presentations. Yokohama, Japan, November 27-30, 2005, pp. 413414.

Narayanamurti D., George J., Pant H.C., and Singh J., 1962. Extractives in teak. Sylvae Genet 11: 57-63.

Nelson N.D., Maeglin R.R., and Wahlgren H.E., 1969. Relationship of black walnut wood color to soil properties and site. Wood Fiber 1: 29-37.

Ngee P.S., Toshiro A., Yoshimura T., Jaal Z., and Lee CY., 2004. Wood preference of selected Malaysian subterranean termites (Isoptera: Rhinotermitidae, Termitidae). Sociobiology 43: 535-550.

Rudman P. and Gay F.J., 1961. The causes natural durability in timber part VI. Measurement of anti-termite properties of anthraquinones from Tectona grandis L.f. by rapid semi-micro method. Holzforschung 15: 117-120.

Rudman P., Da Costa E.W.B., Gay F.J., and Wetherly A.H., 1958. Relationship of tectoquinone to durability in Tectona grandis. Nature 181: 721-722.

Rudman P., Da Costa E.W.B., and Gay F.J., 1967. Wood quality in plus trees of teak (Tectona grandis L.f.): an assessment of decay and termite resistance. Sylvae Genet. 16: 102-105.

Sandermann W. and Simatupang M.H., 1966. On the chemistry and biochemistry of teakwood (Tectona grandis L. fil). Holz Roh- Werkst. 24: 190-204.

Subiyanto, 1995. Pengenalan hama inger-inger pada jati (The identification of teak 'inger-inger' pest). Fakultas Kehutanan Universitas Gadjah Mada, Yogyakarta, Indonesia.

Thulasidas P.K. and Bhat K.M., 2007. Chemical extractive compounds determining the brown-rot decay resistance of teak wood. Holz RohWerkst. 65: 121-124.

Wilkins A.P. and Stamp C.M., 1990. Relationship between wood colour, silvicultural treatment and rate of growth in Eucalyptus grandis Hill (Maiden). Wood Sci Technol. 24: 297-304.

Windeisen E., Klassen A., and Wegener G., 2003. On the chemical characterization of plantation teakwood (Tectona grandis L.) from Panama. Holz Roh- Werkst. 61: 416-418. 